Tér és Társadalom 2. évf. 1988/1. 19-42. p.

1988. 2. éuf. 1. sz. pp. 19-42.

BECSEI JÓZSEF:

\title{
AZ ALFÖLDI KÜLTERÜLETI TÁRSADALOM TAGOZÓDÁSA ÉS TÉRBELI RENDJE 1980-BAN
}

\section{Bevezetés}

Az elmúlt években mintha lecsendesült volna a külterületi településekkel és azok népességével való szenvedélyes foglalkozás. Olyannyira, hogy az 1980-as népszámlálás eredményeinek értékelésére alig-alig került sor, pedig több ok miatt is érdemes a külterületekre odafigyelnünk.

Az elsó ok, hogy 1980-ban az Alföld (a hat alföldi megye és Pest megye alföldi része) 3666478 fós népességének még mindig 8,8\%·a (323642 fó) élt külterületen. Az igaz, hogy ez az 1930-as külterületi népességnek csupán $33,1 \%$-a, de ez a mennyiség még mindig nem elhanyagolható, különösen azokon a területeken, ahol az arányuk lényegesen magasabb, mint az alföldi átlag. A figyelemre kell ösztökéljen bennünket az is, hogy az Alföld aktív keres6́inek 8,9\%-a, az inaktív keres6́knek pedig 18,9 \%-a él a külterületen. Ez utóbbi adat önmagában is azt jelzi, hogy itt olyan társadalmi csoport él és olyan számban, amely - elhanyagolása esetén - különbözö feszültségek forrásává válhat.

A másik ok, amely arra sarkall, hogy az 1980-as adatokat értékeljük az, hogy a magyar statisztika történetében először került sor olyan felvételre, amely a külterületi népességröl külön is részletes feldolgozást adott, igy lehetóvé teszi ezen településcsoport népességének osztály- és rétegtagozódás szerinti elemzését, pontos térbeli rendjének megállapitását. Ez annál is inkább érdeklódésre tarthat számot, mert a magyar társadalom társadalmi csoportok szerinti térbeli rendjével sem a társadalomtudományok, sem a tértudományok nem, vagy csak igen keveset foglalkoztak ezideig. Ahogy mondani szokás, szinte egvik kezünkön megszámolhatjuk azokat (BECSEI J. 1979, 1983, KOVÁCS CS. - FRANCIA L. 1979, BELUSZKY P. 1979, KLINGER A. 1982, SIMÓ T. 1986, SZIRMAI V. 1985, BŐHM A. 1985), akik e kérdéskör elemzésével megpróbálkoztak. A külterületi népességre vonatkozólag ilyen feldolgozás eddig egyáltalán nem látott napvilágot.

Elmondható, hogy a társadalom strukturálódásáról, annak változásairól, föbb jellemzőiről viszonylag bóséges ismeretekkel rendelkezünk, de az egyes területek, régiók helyzete csaknem teljesen feltáratlan. A településtípusok közötti különbségekről is vajmi kevés ismeret áll rendelkezésünkre. Pedig napjainkban, amikor a terület- és településfejlesztés egyre több döntési lehetőséget, jogot, sót kötelezett- 
séget ró a helyi vezetésre, amikor a helyi jogkörök és a megvalósitás anyagi, tárgyi és személyi feltételei nagymértékben felértékelődnek, szükségesnek ítélhető, hogy a társadalom térbeli differenciáiról, azonosságairól, egyáltalán legalább mennyiségi állapotáról valamilyen ismeretanyaggal rendelkezzünk.

Továbbá és másrészt: a társadalom nemcsak belső strukturálódásában, mondhatni tấrsadalmi térben létezik, hanem földrajzi térben, földrajzi kiterjedésben is, $\mathrm{s}$ így települések között oszlik meg. Ezen települések lehetnek kisebbek, nagyobbak。 de kevés olyan speciális eset állt elö, mint a magyar Alföldön, hogy egy sajátos településhez, a tanyához olyan nagy tömeg kapcsolódjon, mint itt. E településtípus nemcsak mint település jelentett és jelent manapság is különlegességet, hanem abban a vonatkozásban is, hogy itt egy speciális társadalmi strukturálódás valósult meg.

Ezért is osztjuk SZIRMAI VIKTÓRIA nézetét, amely szerint ,... a térbeli társadalmi konfliktusok hatékony kezelése, az érdekek érvényesithetősége miatt... szükség lenne a társadalmi rétegek térbeli és strukturális viszonyaira kidolgozott fejlesztési-tervezési koncepcióra.. Ez a koncepció a térben elhelyezkedó népesség konkrét élethelyzeteinek feltérképezését, mindenekelött a különbözó társadalmi csoportok mindennapi életkereteinek, a lakóhelynek, a munkahelynek, a legkülönbözóbb élettevékenységeket magukba foglaló terveknek a megragadását, valamint az élethelyzetek térbeli strukturális meghatározottságának a tisztázását jelenti" (SZIRMAI V. 1985).

Harmadrészt az is megállapitható, hogy miközben a magyar társadalom az elmúlt évtizedekben a gazdasági átalakulás következtében megmozdult, ez a mozgás kettős irányú volt. Mindenekelőtt változott az egyének társadalmi hovatartozása azzal, hogy a társadalmi munkamegosztásban elfoglalt helyzetük változott. De nemcsak az ágazati struktúrában kerültek más helyre, hanem a tulajdonforma tekintetében is új viszony jött létre, s így az egyének más társadalmi osztályba vagy rétegbe csoportosultak át. Ez a társadalmi mozgás az első évtizedekben térbeli mozgással párosult, mig az utóbbi egy-másfél évtizedben a fő tendencia a helyben maradás melletti társadalmi változás volt.

Számunkra most az a kérdés, hogy ezek a folyamatok miként érintették az Alföld külterületi népességét. E tanulmány éppen ezért azt a célt szolgálja, hogy az 1980-as népszámlálás adatai által nyújtott lehetőségeken belül megkisérelje felvázolni az Alföld külterületi népességének társadalmi struktúra szerinti térbeli rendjét. Mivel az elöző népszámlálások - a részleteket illetóen - nem nyújtanak összehasonlító adatokat, egy statikus képet tudunk csak felrajzolni; viszont talán kárpótol bennünket a térbeli változatosság.

\section{A külterületi népesség változása 1949 és 1980 között}

Az Alföld külterületi népessége 1930-tól 1949-ig 130414 fóvel (13,3\%) nőtt, s így 1949-ben az Alföldön élők 33,0\%-a lakott külterületen. A két évtized alatti népességnövekedésnek 38,5\%-a jutott a külterületre. Ez azt jelenti, hogy a külterületi népesség gyorsabban növekedett, mint a belterületi, tehát egy viszonylagos dekoncentrálódási folyamat zajlott ezekben az években az Alföldön. 
Ez azért is figyelmet érdemlö folyamat, mert a városi jogállású települések számában 1930 és 1949 között változás alig volt. Az Alföld városi népességének a száma 22708 fövel nött, de a városok külterületi népessége 136 948-cal növekedett. Ez a gyarapodás nagyobb, mint az egész Alföld népességnövekedése. Ez a változás úgy is érintette az Alföld városait, hogy 1930 és 1949 között e települések belterületi népessége tetemes mértékben (114240 fö) csökkent. Ugyanezen idő alatt a falvak belterületi népessége 90298 fóvel növekedett, külterületi lakosaik száma pedig csökkent (1. táblázat). Igy tehát a falvakban koncentrálódott a népesség, a városokban pedig nagy arányú külterületre áramlás figyelhetö meg. Ez valamennyi nagyobb tanyás városunkat érintette, az egyetlen Debrecen kivételével, ahol a külterületi népesség ez idő alatt 50441 föről 24 446-ra csökkent.

Az Alföld népességének változása 1930 es 1949 között

1. tóblázat

\section{Összes népesség}

Né v

$\begin{array}{lccccccr} & 1930 & 1949 & 1960 & \begin{array}{c}1930 \cdot 1949 \\ \text { száma }\end{array} & \% & \begin{array}{c}1949-1960 \\ \text { száma }\end{array} & \% \\ \begin{array}{l}\text { Városok } \\ \text { Községek }\end{array} & 1009809 & 1032517 & 1007038 & 22708 & 2,2 & -25479 & -2,5 \\ & 2245601 & 2329365 & 2525890 & 83764 & 3,7 & 196525 & 8,4 \\ \begin{array}{l}\text { Alföld: } \\ \text { Összesen }\end{array} & 3255410 & 3361882 & 3532928 & 106472 & 2,2 & 171046 & 5,1\end{array}$

Városok

községek

Alföld

összesen:

$N$ é v

Belterületi népesség

$$
1930
$$

1949

1960

1930-1949
száma

Tényleges szaporodás vagy fogyás

$\begin{array}{rrrrrrrrr}666700 & 552460 & 827112 & -114240 & -17,1 & 274652 & 49,7 \\ 1611326 & 1701624 & 1932395 & 90298 & 5,6 & 230771 & 13,6 \\ & & & & & & & \\ 2278026 & 2254084 & 2759507 & -23992 & -1,1 & 505723 & 22,4\end{array}$

A külterületi népesség

Név

$\checkmark$ árosok

Községek 1930

1949

343109

480057

634275

627741

593495

1960

1930-1949
száma

Tényleges szaporodás vagy fogyás

Alföld összesen:

$977384 \quad 1107798$

773421

130414

$\begin{array}{llll}13,3 & -334377 & -30,2\end{array}$ 

Tér és Társadalom 2. évf. 1988/1. 19-42. p.

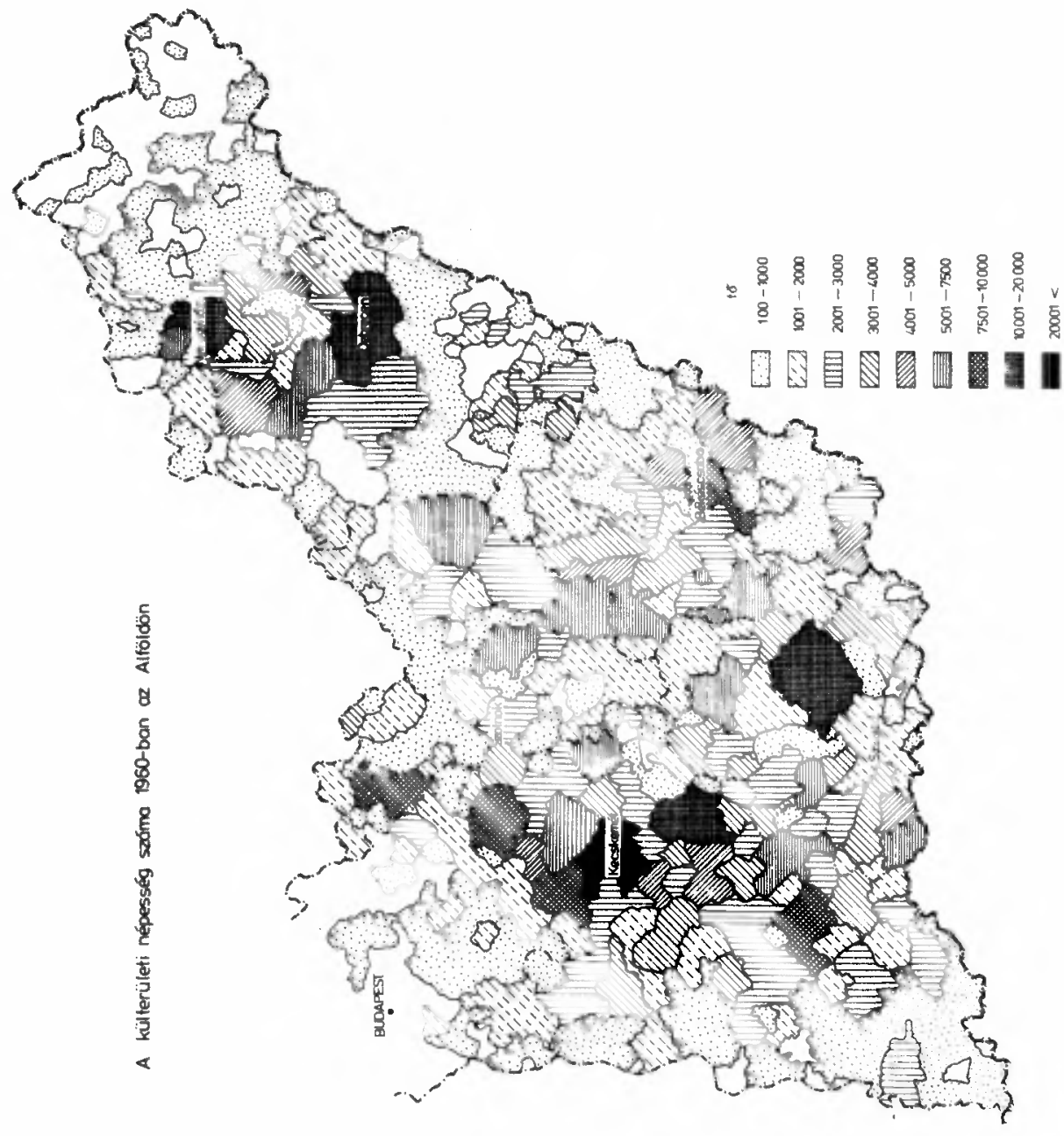




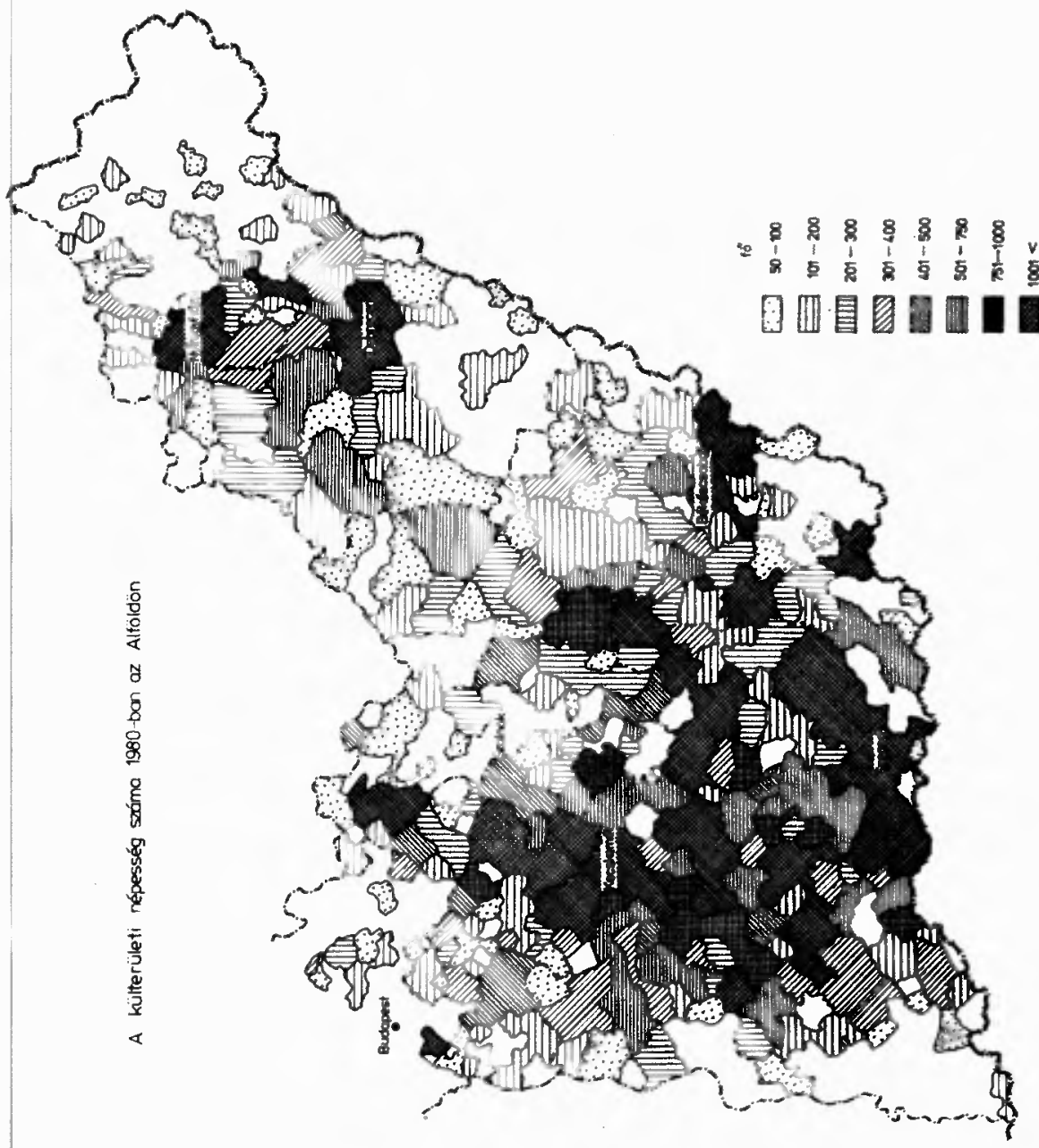


Az 1949-ben külterületen élt lakosságot a fentieken túl a feltünöen fiatalos korösszetétel jellemezte, ami egyrészt a 15 éven aluliak magas $(27,1 \%)$, másrészt a 60 éven felüliek alacsony hányadában jutott kifejezésre. Igaz viszont, hogy a munkaképes korú népesség 61,4\%-os részesedése alacsonyabb az országos (63,5\%) átlagnál. Szabolcs-Szatmár, Szolnok és Bács-Kiskun megyék különösen alacsony értékekkel tünnek ki.

Az a hatalmas változás, amely az egész magyar tanyarendszerben 1949-től napjainkig lezajlott, az 1950 es években indult el. Ezen idő alatt az Alföld külterületi népessége 30,2 \%-kal csökkent. Ez a csökkenés nemcsak területileg volt differenciált, hanem az egyes településtípusok esetében is. A csökkenés kevésbé volt viharos a falvakban $(5,5 \%)$, mint a városokban. A városokra esett az összes fogyás $89,8 \%$-a (300 131 fö). A városok népesedésére ezen túl az volt a jellemzö, hogy az összes városi lélekszám 2,5\%-kal (274 652 fö) nőtt. ( $A$ várossá nyilvánitott települések sora csak Törökszentmiklóssal növekedett!) Egyfelöl tehát megfigyelhetjük a népesség koncentrálódását a városok belterületére, ami a tényleges szaporodásból, illetve a külterületröl a belterületre való beáramlásból táplálkozott. ( $A z$ 1960. évi népszámlálás adatai alapján az Alföld valamennyi városában pozitiv volt a tényleges szaporodás, a mi adataink szerint pedig a városi népesség csökkent. Ez azért állt elö, mert mi az 1949-es népszámlálási kötet adatait vetettük össze az 1960-as adatokkal, s a két cen. zus között a városok területe 330943 hektárral csökkent. Az 1960-as népszámlálásnál a tényleges szaporodási adatok 1949es értékeit erre a csökkent területre számították át.) Ez alatt az idő alatt - elsősorban a városok határából - számos tanyaterületet önálló községgé nyilvánitottak, így a községi népesség száma növekedett. Ezen településtípusnál is - bár a folyamat lassúbb ütemü - tanúi lehetünk a népesség belterületen való koncentrálódásának.

A külterületi népesség fogyása elsősorban a munkaképes korú népességet érintette, hiszen az 1949-es 61,4\%-os arányuk 1960-ra lecsökkent 59,1\%-ra. A 0-14 évesek hányada 30,2 \%-ra növekedett, és csökkent a 60 - X évesek aránya 10,7 \%-ra. $A z$ egész népességnek 50,2 \%-a a mezögazdaságban, 7,3\%-a az ipar és épitőiparban és $8,2 \%$-a az egvéb ágazatban dolgozott.

E helyen nem tartom feladatomnak a külterületi népesség számában végbement további változást (csökkenést) elemezni (1-2. ábra), néhány fontosabb észrevételt mégis szükséges tenni. 1960-ban az Alföld településeinek többségében a külterületi népesség abszolút száma meghaladta az 1000 föt, Debrecenben, Hódmezővásárhelyen, Kiskunfélegyházán és Nyíregyházán 10000 fölött volt a számuk, sőt Kecskeméten több mint 20000 fö élt külterületen. A két évtized (1960-1980) vál. tozásának fő következményei:

1/ Egész térségek váltak külterületi népesség nélkülivé, vagy olyan területekké, ahol e településekben élök száma oly kevés, hogy elemzése elhanyagolható. llyen területek: Szabolcs-Szatmár megye túlnyomó többsége, Hajdú-Bihar és Békés megyének elsősorban a volt bihari részei, Békés megye volt arad-csanádi részei, Szolnok jászsági részei, a Tisza mente, Pest megyének a fövárosi agglomerációt alkotó jelentős terü. letei, a Bácska jelentős része, továbbá a Duna mente.

2) A nagyobb külterületi népességgel rendelkező települések sávokban, illetve gócokban helyezkednek el. Igy a Hajdú és Szabolcs megyei övezet, a közép-békési öve- 
zet, a nagykun városok, a Duna-Tisza közi Homokhátság egésze, a csongrádi városok és végül Jászberény és közvetlen környéke alkot egy-egy nagyobb egységet.

3/ A külterületi népességgel rendelkezö települések többségében a külterületi népesség száma 100 és 1000 között mozog, az 1000 föt 32-ben haladja meg és egy kisebb csoportban 50 és 100 fö között van a számuk.

A külterületi népességnek e nagysága és térbeli megoszlása azt mutatja, hogy az Alföld egészén végbement mennyiségi változás olyan mértékü volt, hogy az már minöségi ugrást jelent. Ennek egyik pólusát egy relatíy koncentrálódás jelenti, mig a másikat a külterületi települések teljes megszúnése.

Amikor ma e népesség minöségi jellemzőit keressük, mindenkor figyelemmel kell lennünk arra, hogy azok mögött jóval kisebb abszolut értékek szerepelnek, mint amikor az Alföld valóban tanyás terület volt. A külterület jellegzetességei kevésbé nyomják rả bélyegüket az egész település életére, mint a korábbi évtizedekben (2. táblázat).

Számunkra a mennyiségi csökkenés ellenére is fontos kérdés marad azonban az, hogy a társadalmi-gazdasági változások milyen mértékben alakitották át azokat a külterületen élöket, akik mind a mai napig nem mozdultak onnan, sót egyes területeken elköltözésükkel a jövöben sem számolhatunk.

\section{Osztály- és rétegtagozódás}

1980-ban az Alföldön a külterületen élök száma 325208 fö volt, az összes lakos 8,6 \%-a. A keresök 211208 fös (64,9 \%-a) táborából az aktiv keresök 150070 föt $(46,1 \%)$ foglaltak magukba, ami pontosan megegyezett az alföldi összes aktív keresők arányával.

A következőkben a társadalom struktúrájának 1980-as állapotát mutatjuk be, mégpedig a tulajdonviszonyok alapján kialakitható réteg- és osztályszerkezet föbb jellemzóit. Általánosan ismert az a vita, amely a társadalom strukturálódásával kapcsolatosan napjainkban is folyik, s amelynek alapján lényegében három markánsan megje lenő nézet különithető el (HALAY T. 1982, BARANYI B. 1985). Mi úgy gondoljuk, hogy a társadalom valamely népességcsoportjáról annál adekvátabb képet kapunk, minél több oldalról igyekszünk annak belső jellemzóit megkeresni. Célunk nem is az, hogy a társadalom strukturálódásáról folyó vitához hozzászóljunk, hanem - elfogadva a statisztika nyújtotta kategóriákat - e struktúra térbeli megjelenését Irjuk le.

Ahhoz, hogy egy nagyobb területröl a címben jelzett elemzés készülhessen, jelenleg - más forrás nem állván rendelkezésünkre - kénytelenek vagyunk elfogadni a népszámlálási kötetek statisztikai adatait, s az azok mögött meghúzódó osztály- és rétegtartalmakat, amelyeket ma már sokan vitatnak. Valóban joggal felvethető az a kérdés, éppen a külterületen élö mező- és erdőgazdálkodási aktiv keresók kapcsán, hogy mennyiben jogosult pl. az állami gazdasági és termelöszövetkezeti dolgozót különböző osztályba sorolni, hogy a tulajdonformán túl mennyiben különbözik egymástól e két csoport, illetve összes többi életmegnyilvánulásában melyikhez áll közelebb az állami gazdasági dolgozó: a gyári munkáshoz-e vagy a termelöszövetkezeti paraszt- 


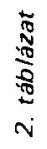

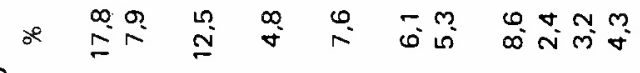

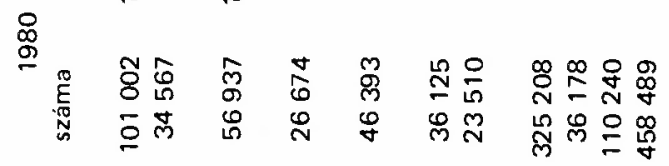

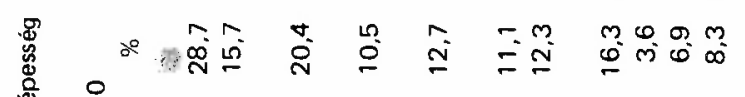

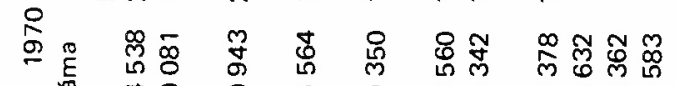

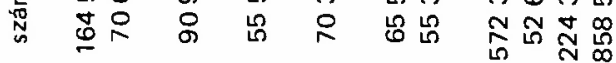

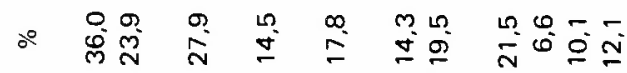

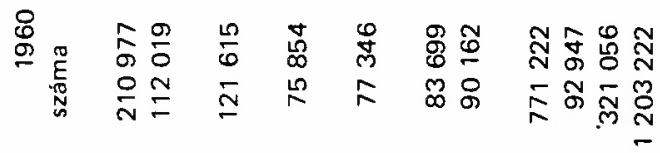

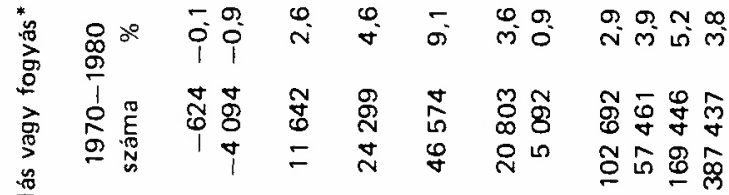

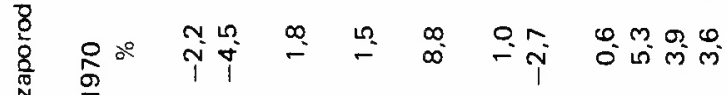

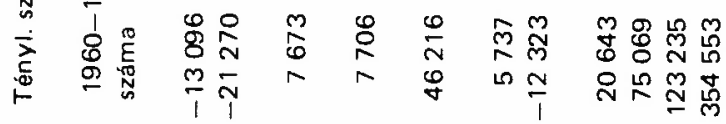

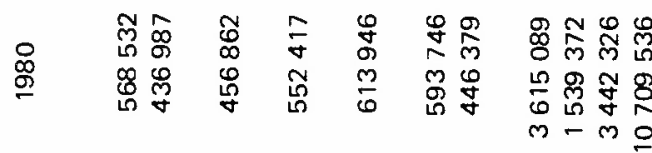

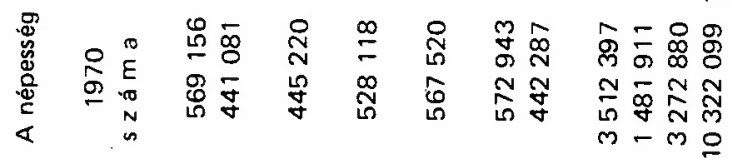

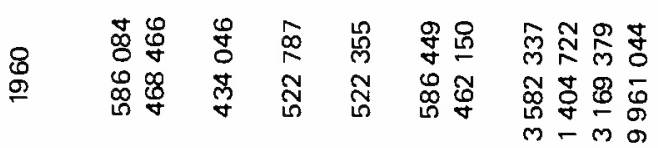

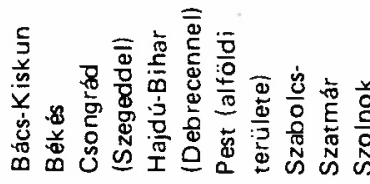

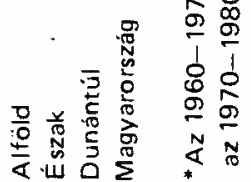

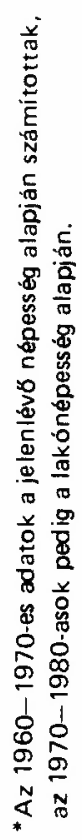

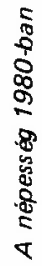


hoz (SIMÓ T. 1984)? Vagy egy másik kérdés: a korábbi évtizedek során végbement osztály- és rétegeltolódások az 1970 es éveket már nem jellemezték, hanem - a társadalmi-gazdasági fejlődés velejárójaként - a belső szerkezet minóségi átalakulásának szakasza kezdődött meg (KLINGER A. 1982). Ez a megállapítás országosan igaz lehet, de vajon az Alföld külterületi népességére vonatkozólag is ilyen egyértelmú lenne? Az idézett szerző megjegyzi, hogy a nagymértékủ számszerü változások helyett az egyes osztályok és rétegek összetételének belső átrendeződése vált jellemzóvé, ami a képzettségi szint emelkedésében, az ágazati és foglalkozási szerkezet átalakulásában és a területi arány eltolódásában jutott kifejezésre. Mindebben a folyamatban a külterületi népesség aktivan részt vett, az őket is érintette, de bizonyos fáziseltolódással. Söt: ma is aktív részesei ennek a folyamatnak, még akkor is, ha az össztársadalmi arányokat az ott folyó átalakulás alig érinti.

Az a tény azonban, hogy a külterületi népesség 1970 és 1980 között az Alföldön tetemes mennyiséggel (247 170 fö, az Alföld népességének 7,0 \%-a) fogyott, ugyanakkor a mezőgazdaságban dolgozók száma összesen is és a külterületen is csökkent, arra utal, hogy ez a népesség nemcsak lakóhelyét változtatta meg, hanem foglalkozását is, egyik tulajdonformából átkerült egy másikba, így egvik osztályból átlépett egy másikba. Ez a népesség-csökkenés a ma külterületen élök 76,0 \%-ának felel meg, tehát az itt élôk szempontjából ez a változás döntő jelentőségúnek ítélhetỏ. Békés megyében például a külterületen élő fizikai aktív keresők száma 1970 és 1980 között 13617 fövel csökkent s ez a jelenleg ott éló fizikaiaknak 92,3\%-át jelentette, vagyis a külterületen élt fizikai foglalkozásúaknak $48,0 \%$-a, a szellemi foglalkozásúaknak pedig 42,2 \%-a változtatott lakóhelyet.

Az eddigiek is bizonyítják, hogy a külterületi népesség osztály- és rétegtagozódásának kérdései izgalmas problémákat rejtenek magukban. Sajnálatos, hogy a hiányzó adatok miatt csak statikus képet tudunk felvázolni. Ezen túlmenóen is számos módszertani probléma vetődik fel a kutatás kapcsán. Így mindenekelött az, hogy melyik legyen az a legkisebb abszolút szám vagy arány, amelyik mellett még az adott települést külterületileg lakottnak tekintsük. Ha nem alkalmazunk megszorításokat e vonatkozásban, akkor a térképi ábrázolásnál egy kategóriába kerülhet az a település, ahol a munkásosztályhoz tartozók száma csupán 2 volt, azzal, ahol a számuk meghaladta az 1000 föt is. Igy első lépésben a statisztikailag megadott négy osztály- és rétegkategórián belül 2-2 csoportot képeztem (uralkodó és domináns). amelyek függetlenek voltak az abszolút nagyságtól, a besorolást a relatív értékek alapján végeztem el (3. ábra). A második lépésben abszolút értékeket is beiktattam, mégpedig az aktiv keresők viszonylagos értékeit, aminek alapján több településünk kiesett a vizsgálatból. Fzt tovább szigorította az a kritérium, hogy legalább 100 külterületi lakosnak kellett ahhoz lennie, hogy az adott település a végsỏ kategóriákba bekerülhessen (4. ábra). Ez az értékelés, ha nem is hibátlan, de a tapasztalati tényekkel jól egybeeső képet adott. 


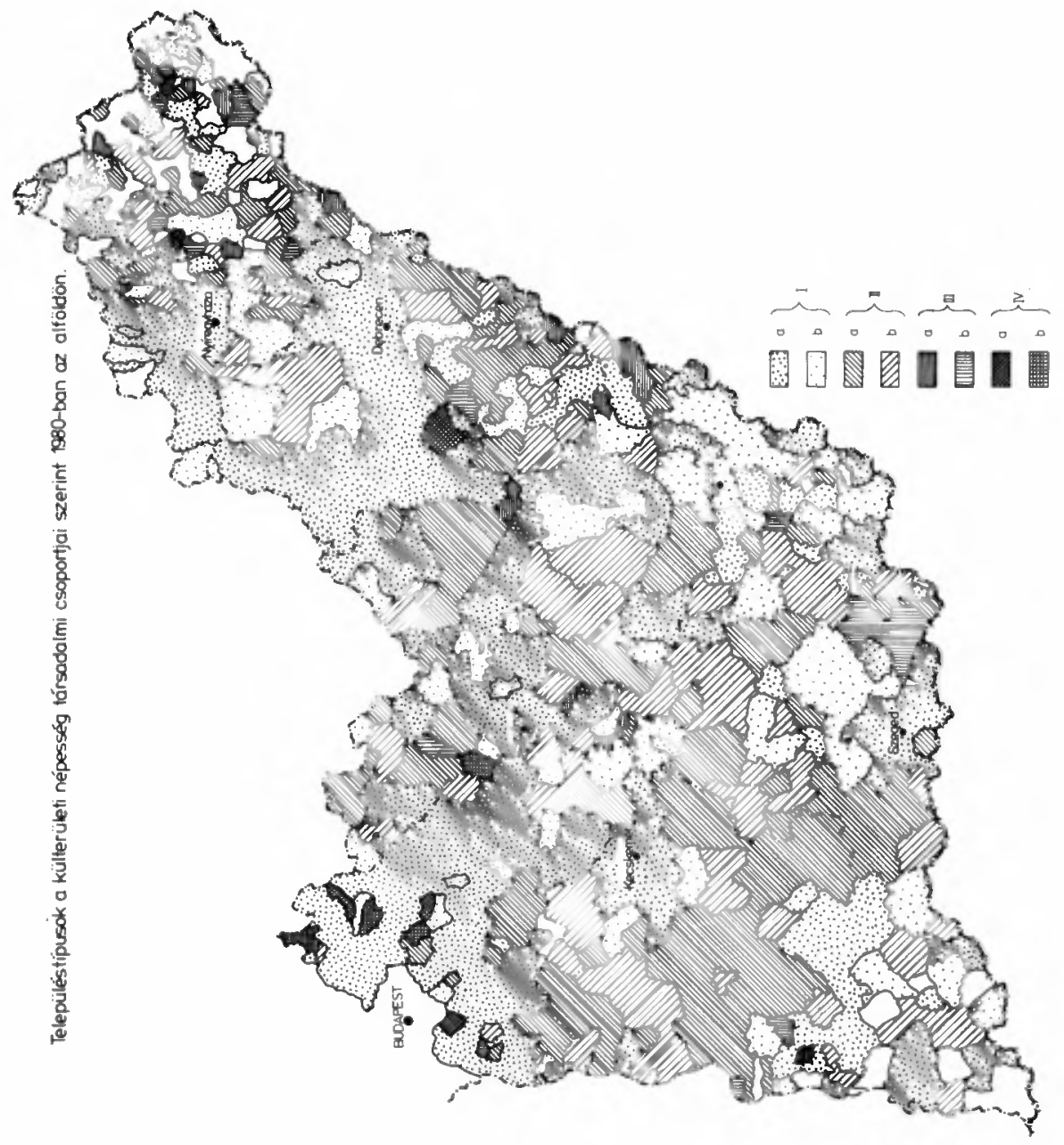

\section{3. ábra}

I: munkásság, II: termelöszövetkezeti parasztság, III: kisárutermelö, kiskereskedő, IV: értelmiségi, a: uralkodó társadalmi csoport $(50,0 \%$ felett $)$, b: domináns társadalmi csoport $(33,4-50,0 \%)$. 


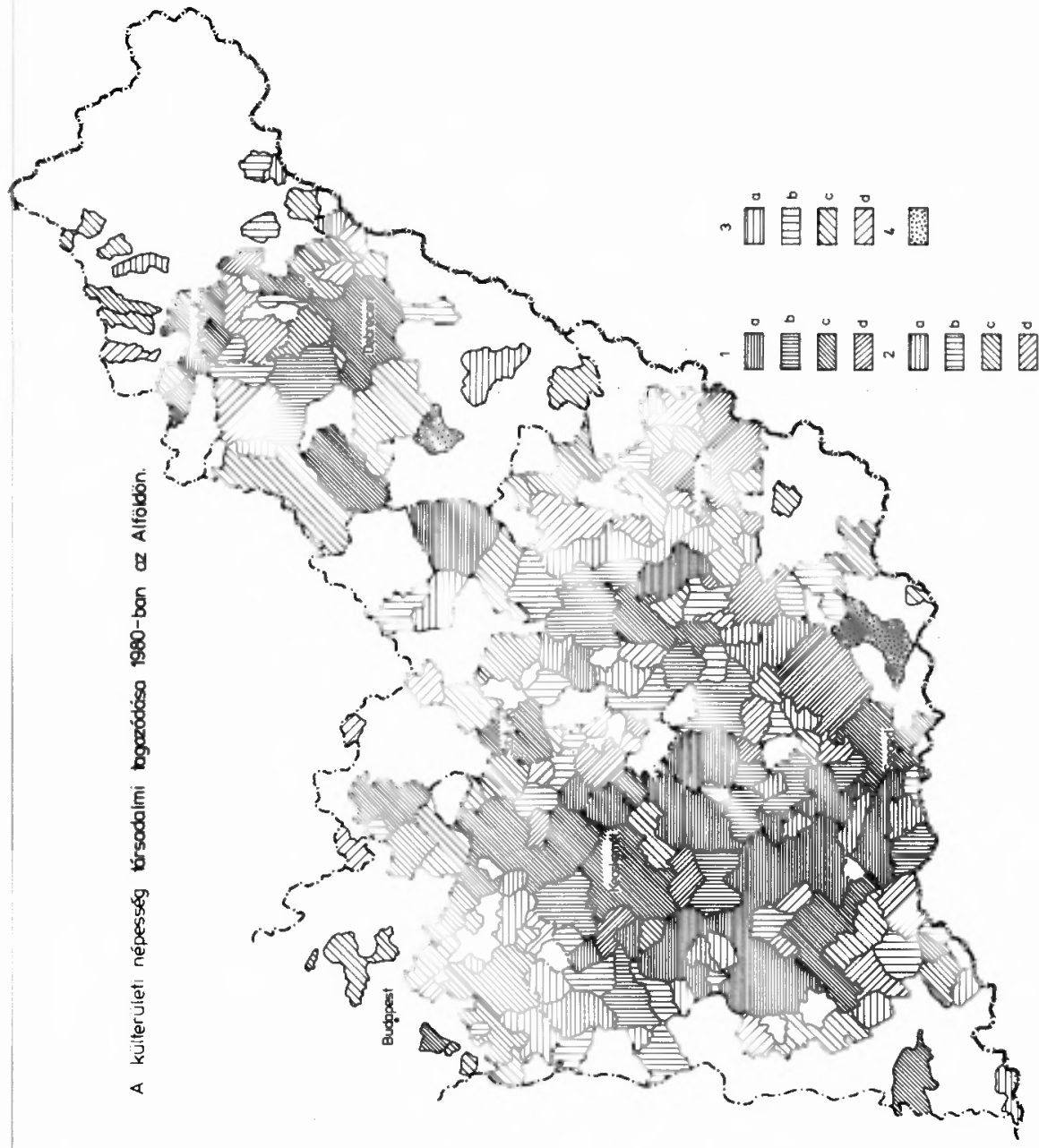

\section{4. ábra}

1: $50,0 \%$ feletti külterületi aktiv keresó és 500-nál több külterületi lakos, 2: 35,1 - 50,0 \% külterületi aktív keresó és 301 - 500 külterületi lakos, 3: 20,1 - 35,0\% külterületi aktív keresó és 101 - 300 külterületi lakos; a: uralkodóan parasztság, b: dominánsan parasztság, c: uralkodóan munkásság, $d$ : dominánsan munkásság. 


\section{A munkásosztály}

A munkásosztály létszáma az Alföldön 1970-ben 818697 fö volt, ami 1980 . ra 911101 före nött. (Most és a továbbiakban is csak az aktiv keresőket véve figyelembe.) Ez az összes kereső $53,9 \%$-át jelentette. Növekedési dinamizmusuk $(11,3 \%)$ gyorsabb volt, mint az országos $(5,9 \%)$ átlag. Az Alföld külterületén élt 1980-ban a munkásságból 73940 fö, az összesnek 8,1\%-a, ami kisebb részesedést jelent, mint az összes aktiv keresőnek $(8,9 \%)$ a külterületen lévő hányada. Az összes külterületi keresônek 49,3 \%-a tartozott ekkor a munkásosztályhoz, s ez a magas arány azt jelenti, hogy megelözte a termelöszövetkezeti parasztság és a többi csoport részesedését is. Vagyis, ha nem is olyan dominánsan, mint az Alföld átlagában, de a munkásosztály mégis a legnagyobb létszámú osztállyá fejlödött a külterületen is.

Jelentős eltérés figyelhető meg a városok és falvak értékei között. Az Alföld városainak külterületén élt keresök 60,0\%-a tartozott a munkások táborához, ami a külterületi munkások $37,7 \%$-át jelentette. Ugyanakkor a másik oldalon a falusi települések külterületén a munkásság az aktív keresők 44,5\%-át adta, az összes külterületi munkás $62,3 \%$-át. Tehát akiket a statisztika a munkásosztályhoz tartozónak tekintett, azok a társadalmi munkamegosztásban elfoglalt helyük alapján is nagyobb hányadban éltek a városok külterületén. Más szóval: a külterületi munkásság nagyobb arányban kötödik települési helyével a fejlettebb településtípushoz, a városhoz, mint a falvakhoz (3. táblázat).

A városok nemcsak abban az értelemben tekinthetök fejlettebbeknek, hogy a belterületek népességösszetétele kedvezóbb, mint a falvaké, továbbá, hogy a városok több és nem az agrártermeléshez kötött munkahelyet biztositanak, hanem abban is, hogy a városok külterületi népességének összetétele is kedvezöbb struktúrájú, mint a falvaké. Így a városok külterületén a $0-14$ évesek aránya $(21,3 \%)$ magasabb, mint a falvakban $(19,9 \%)$, ugyanakkor a 60 -X évesek hányada $(17,6 \%)$ alacsonyabb, mint a falvakban $(20,5 \%)$. Hasonló különbségeket találunk akkor is, ha az iskolai végzettséget vetjük össze. Ami tehát azt is jelenti, hogy a városok külterületi munkásságának belsó strukturálódása is kedvezöbb, mint a községeké (4. táblázat).

$A z$ egyes megyéket a munkásság külterületi aránya alapján különböző típusokba lehet sorolni (5. ábra). Az egyik csoportba Hajdú-Bihar, Pest és SzabolcsSzatmár megye tartozik, ahol megyei átlagban az arányuk megközelíti a 60 \%-ot. Azonban az egyes megyék között itt is fontos eltérések jelentkeznek. Pest megye az Alföld egyetlen megyéje, ahol a községek külterületén magasabb a munkások aránya, mint a városokén. A Pest megyei községi átlagtól $(58,6 \%)$ alig marad el HajdúBihar megye községi átlaga $(57,6 \%)$, de ebben a megyében a városi átlag $60 \%$ fölé emelkedik. Szabolcs-Szatmár megye pedig azért foglal el különleges helyet, mert itt a városi átlag $(68,4 \%)$ olyan magas, hogy ezzel az Alföldön a legmagasabb értéket mondhatja magáénak. Igaz viszont, hogy falusi értéke az alacsonyabbak közé tartozik.

A másik csoportot Bács-Kiskun, Békés és Szolnok megyék alkotják, ahol a megyei átlagérték $50 \%$ alatt, de $40 \%$ felett helyezkedik el. Közülük Bács-Kiskun azzal különül el, hogy a városi és falusi értékek között igen nagy az eltérés $(17,2 \%)$, míg Szolnok megyében a viszonylag alacsony átlagértékek az említésre méltóak. 
ח

Nल

$n=0$
$=\infty \infty$

$\infty 0^{\circ}$

$0 \%$

त्र

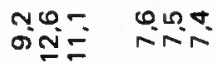

高

ิํํ용

กิ๊ ฒั

ธกตู่

พํํำ

MN

เి

ํํำํำ

ป⿻ำ

N

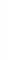

荡

Tำ

ำ
No

ตับับ

Tó

$-\infty \sigma$

$=00$

Nका
Nएक

$\infty 0^{\circ}$

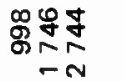

กำ

ธํํำ

ํํำ

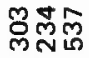

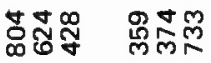

$\infty \underset{0}{\infty}$

mo

芯

นุก

赵守

0.100

$2 \pi$

$0 \infty 0$

$00 \%$

$\infty \infty \sigma$

0.2

N

ल ले

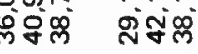

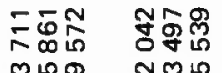

ल)

Mon

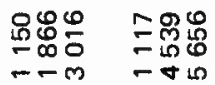

๓⿴囗十ㅇำ

ติกั

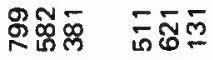

mष -N寸 MुR

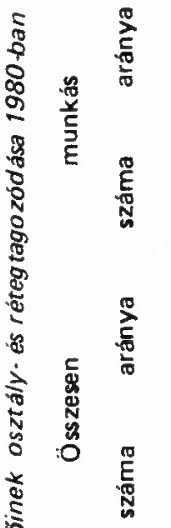

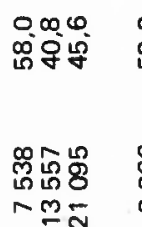

ํำ

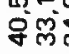

$-60$

$-6 m$

$\operatorname{Rng}$

Q.19N

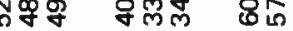

解品

8 \&

fㅇำ

8 舟字

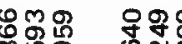

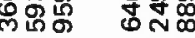

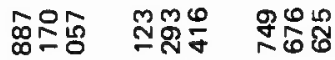

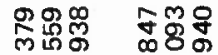

NRO NणR NaE

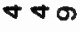

Nกษ กับ

\begin{tabular}{|c|c|c|c|c|c|c|c|}
\hline 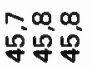 & 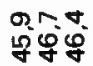 & $\begin{array}{l}\text { ㄸo } \\
\text { 용요 }\end{array}$ & $\begin{array}{l}9-N \\
8+5\end{array}$ & $\begin{array}{l}0.0 \\
y+9\end{array}$ & $\begin{array}{l}0 \infty \omega \\
0 \& 10\end{array}$ & gं & $\dddot{y}$ \\
\hline 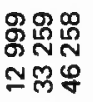 & 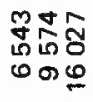 & 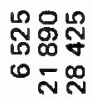 & 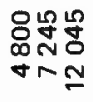 & 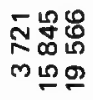 & $\begin{array}{l}0100 \\
905 \\
000\end{array}$ & 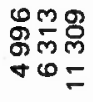 & 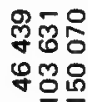 \\
\hline
\end{tabular}
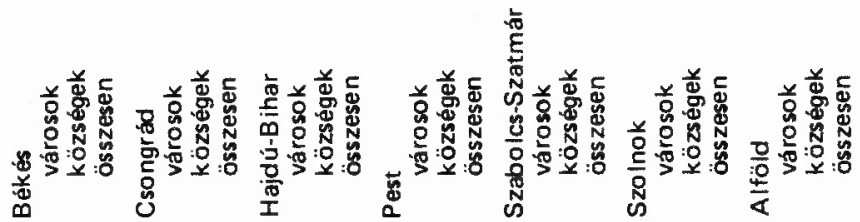
क ष 0 .

車

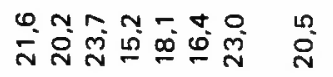

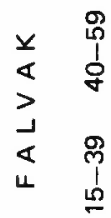

L 2.40.

ஸั

(2)

$\infty$

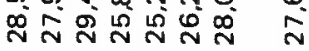

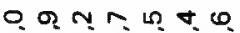

लं ल ल ले फ्ल ले लू

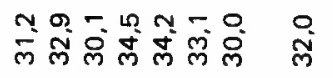

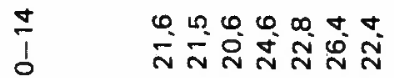

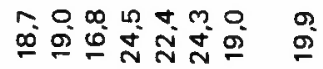

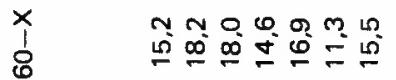

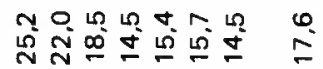

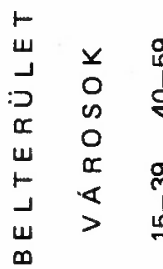

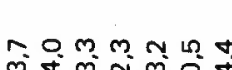

$\vdash$

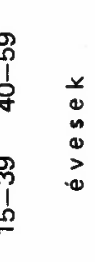

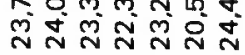

w

กิ

ш

\& $=0$ 누

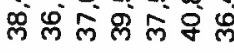

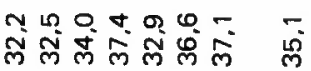

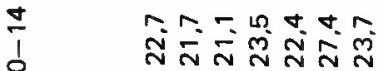

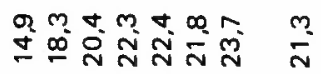

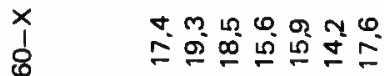

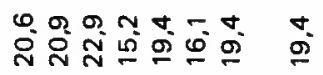

$\begin{array}{ll}z & g \\ w & 1 \\ \omega & 8 \\ w & \\ N & \\ \omega & g \\ \omega & 1 \\ 0 & \text { 요 }\end{array}$

m.

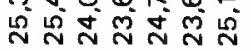

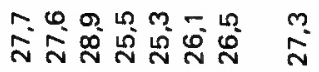

m.

พัพ

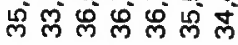

लं ले ले लं लू लू

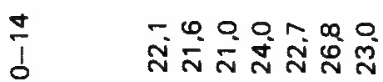

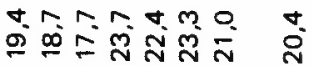

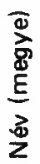

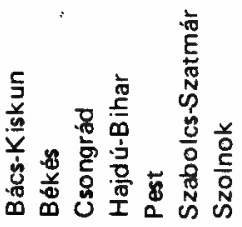

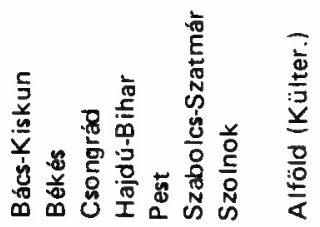


Viszonylag kiegyensúlyozott helyzetet tükröznek Békés megye értékei, ahol a megyei átlag csaknem egybeesik az alföldi átlaggal. Ezekben a megyékben a munkásosztályhoz tartozók arányuk alapján még a legnagyobb társadalmi csoportot alkotják, de nem olyan domináns értékkel, mint az előbbi három megyében. Velük még leginkább Békés megye lenne egy sorba hozható.

Egészen különleges helyzetet mutat Csongrád megye. Itt a megyei átlag csupán $34,8 \%$, tehát az egésznek az egyharmadát alig haladja meg. A falusi átlag csupán $33,1 \%$, de a városi is csak $40,5 \%$. Ebben a megyében a „,foglalkozási urbanizáció” a külterületet a legkevésbé alakította át. A városok külterületén is alacsonyabb a munkások aránya, mint öt alföldi megyénk (Bács-Kiskun, Békés, Hajdú-Bihar, Pest, Szabolcs-Szatmár) községeinek külterületén. Egyetlen olyan megyéje az Alföldnek, ahol a termelöszövetkezeti parasztság aránya magasabb, mint a munkásoké, sőt arányuk egyedül itt mutat domináns értéket. Ezt a helyzetet részben a Csongrád megyei települési renddel, részben az ott folyó gazdálkodással, továbbá a történelmi hagyományokkal magyarázhatjuk, de szerepet játszik benne a Csongrád megyei városok - Szeged kivételével - viszonylag alacsony iparosodottsági szintje is.

A külterületi munkásság településenkénti arányát a 3. ábra mutatja be. Az ábrán négy csoportba, összesen nyolc kategóriába soroltam be a településeket. $A$ négy csoportot a társadalmi osztályok és rétegek adják, míg ezeken belül megkülönböztettem uralkodó $(50,1 \%$ feletti) és domináns $(33,4-50,0 \%)$ arányt. Vannak tehát olyan települések, ahol a termelószövetkezeti parasztság van dominánsan jelen, $s$ ahol a munkások arányát az ábra nem mutatja. (Csupán azon településekben, ahol arányuk meghaladja a 33,3 \%-ot, s ezzel egyben a legnagyobb társadalmi csoportot képviselik.)

Azok a települések, ahol a vezető társadalmi csoport a munkásság, az Al. föld nagyobbik hányadát foglalják el: Pest, Békés, Hajdú-Bihar és Szabolcs-Szatmár megyék csaknem egész területét uralják és jelentős területekre terjednek ki Szolnok megyében is. Csongrád megyében csupán Szeged és Hódmezóvásárhely és közvetlen környékük tartozik ide, míg Bács-Kiskun megyéböl Kecskemét és környéke, valamint a délnyugati részen egy nagyobb, de nem összefüggő övezet tartozik ide. Az egyes területek között azonban fontos különbségek is vannak. Amíg ugyanis a Pest-Bács. Kiskun-Szolnok megvei csaknem összefüggö övezeten belül a munkások 50 \% feletti arányban vannak jelen, addig Békés megye területének nagyobbik részén csak dominánsan. Továbbá: Hajdú-Bihar megye nyugati-délnyugati sávjában a többség csak azért alakulhatott ki, mert itt magas az állami gazdaságokban dolgozók aránya.

Ma már az Alföld külterületi településein az aktív keresők a legnagyobb számban a munkásosztályhoz tartoznak. Meghatározó jelentőséggel vannak jelen nemcsak az iparosodottabb városok, hanem a falvak határában is. Területi elterjedtségükben lényeges különbségek mutatkoznak, amelyek kialakulásában a történelmi múltat, a jelenlegi gazdasági formát, a települési rendet és a belterületen lévő gazdasági bázist, valamint a kül- és belterület között kiépitett közlekedési kapcsolatokat egyaránt szá. mításba kell vennünk. 


\section{A szövetkezeti parasztság}

A társadalmi munkamegosztásban elfoglalt hely, valamint az osztályok szerinti besorolás közötti jelentös különbség elsösorban a mezógazdaságban dolgozók és a szövetkezeti parasztság kategóriái között a legszembetünóbb. A külterületen élö aktív keresốk esetében különösen nagy az eltéi és (5. ábra), hiszen az Alföldön a mezö- és erdögazdaságban dolgozók száma 86748 fö, s közülük csak 57131 fó tartozik a szövetkezeti parasztság soraiba. Többek között ezért is jelenti ez a probléma az egyik legfontosabb vitakérdést a társadalom strukturálódásáról, illetve osztálytagozódásáról folytatott polémiában. Az állami gazdaságok és termelöszövetkezetek fizikai dolgozói között általában nem a tulajdon a leginkább differenciáló tényezö, hanem egyéb adottságok és helyzetek váltak meghatározó jelentőségüvé. A tapasztalati tények alapján méginkább érvényesnek tekinthetó ez a külterületen éló mezőgazdasági foglalkoztatottakra, illetve a hozzájuk kapcsolódó családokra. A foglalkozási szerkezet igy sokkal inkább paraszti társadalomnak mutatja a külterületi népességet, mint az osztályszerkezet szerinti besorolás. Az elmúlt két és fél évtizedben a szövetkezeti parasztság - és közöttük a külterületen élók - munkafeltételei, életkörülményei, jövedelmi viszonyai stb. gyorsabban változtak, így a két szektor közötti különbségek csökkentek, vagyis nem további differenciálódás, hanem közeledés következett be.

Mindezek ellenére a szövetkezeti parasztságot a maga specifikus jegyei alapján a társadalom olyan nagy csoportjának tekinthetjük, amelyen belül - a társadalmigazdasági-kulturális folyamatok által meghatározottan - olyan sajátos fejlödési folyamatok zajlottak, s történnek napjainkban is, amelyek nem elhanyagolható specifikumokat teremtettek, s amelyek ismerete nélkül, vagy azok figyelmen kívül hagyása esetén éppen a társadalomról alkotott teljesebb ismeretünkról mondanánk le.

1980-ban az Alföld külterületén a szövetkezeti parasztság a keresők 38,1\%-át adta, míg a belterületen csupán 17,0 \%-ot tett ki. Az összes szövetkezeti parasztnak $17.9 \%$-a élt külterületen (3. táblázat). A külterületi keresókből való részesedésük tehát lényegesen meghaladja a belterületi arányukat, illetve a külterületi népesség részesedési arányát az összes népességböl. Így a szövetkezeti parasztság a kedvezőtlenebb helyzetü külterületi településekben koncentrálódik, ezen belül is elsősorban a községek határában él, hiszen az összes külterületi szövetkezeti paraszt 75,4 \%-a itt található. A belterület oldaláról szemlélve pedig azt mondhatjuk, hogy a városi szövetkezeti parasztság inkább a külterületen él $(25,6 \%)$, mint a falusi, hiszen az egész falusi szövetkezeti parasztságnak csupán 16,4 \%-a él külterületen.

A megyék külterületét vizsgálva megállapítható, hogy egyedül Csongrád megye az, ahol a szövetkezeti parasztság aránya meghaladja az 50 \%-ot, mégpedig úgy, hogy arányuk mindkét településtipus külterületén magasabb, mint a munkásság aránya. A városi és a falusi külterüteti arányok $(41,9 \%, 54,7 \%)$ is magasabbak, mint a többi megye hasonló értékei. Csongrád megyét tehát nemcsak a mezögazdaságban dolgozók aránya alapján, hanem pusztán a szövetkezetiek alapján is a leginkább agrár külterületi megyének tekinthetjük.

A többi megyét (éppen úgy, mint a munkásság arányai alapján) két nagyobb csoportba sorolhatjuk. Az egyikbe Bács-Kiskun, Békés és Szolnok megyék tartoznak, 


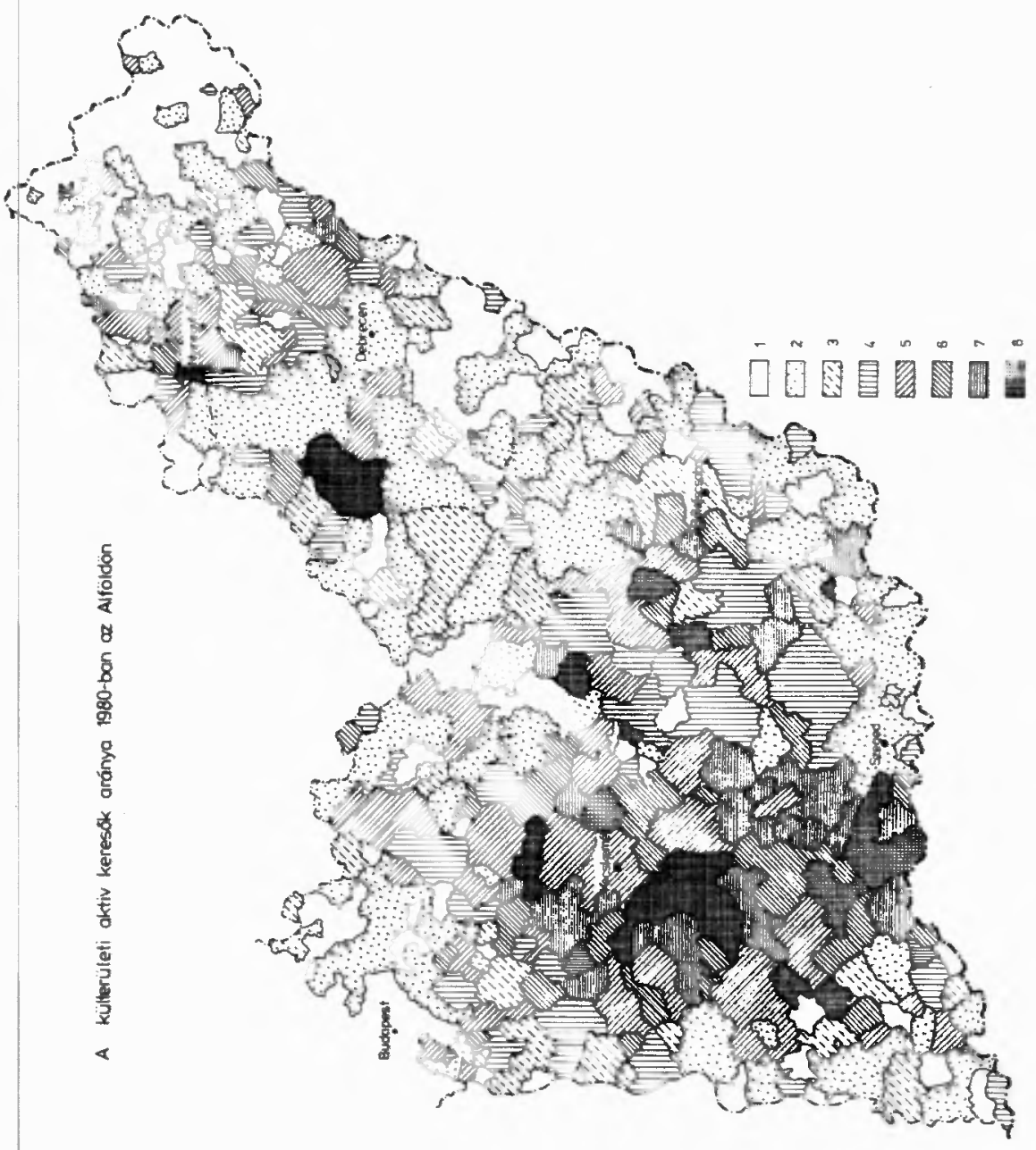

\section{5. abra}

1. 10 fó alatt, 2 : az országos átlag alatt $10,1-4,4 \%$, 3: az alföldi vấrosi átlag alatt $(4,5-6.7 \%)$, 4. az alfóldi községi átlag alatt $16,8-10,4 \%, 5: 10,5-20,0 \%, 6: 20,1-35,0 \%, 7: 35,1$ $50,0 \%, 8: 50,0 \%$ felett. 
ahol a munkásság aránya ugyan magasabb, mint a szövetkezeti parasztságé, de a kettő közötti különbség nem jelentös. Bács-Kiskun megyében a falusi és városi értékek között ugyanúgy nagy különbség $(19,2 \%)$ mutatkozik, mint a munkások esetében, csak most a falusi települések javára. lgy Bács-Kiskun megye városi külterülete kevésbé agrárjellegü, mint az ezen csoportba tartozó másik két megyéé, ellenben községei külterülete sokkal inkább a szövetkezeti parasztság lakóhelye, mint a többi megyéé, $s$ ebben a tekintetben Csongrád megyéhez áll közelebb.

A másik csoportba Hajdú-Bihar, Dest és Szabolcs-Szatmár megyék tartoznak, ahol a szövetkezeti parasztság jelenlétét alacsony értékek (30\% alatt) jellemzik. Ezek sorában a legkiugróbb Szabolcs-Szatmár megye 13,8\%-os városi értéke, s ezzel az Alföldön a legalacsonyabb csoportértéket produkálja. Ugyanitt a községek értéke $34,8 \%$, tehát jelentős különbség $(21,0 \%)$ van a községi és városi értékek között. Az általános alföldi képtöl abban is különbözik ez a megye, hogy a községekben a szövetkezeti parasztságnak csupán 7,2 \%-a él külterületen (az átlag 16,4 \%), míg a városok esetében az átlagnál $(25,6 \%)$ magasabb $(38,8 \%)$ arányt tapasztalunk. Pest és Hajdú-Bihar megyében viszonylag egvenletesnek tekinthetőek a városok és a községek átlagos értékei, de amíg Hajdú-Biharban a városi szövetkezeti parasztságnak csupán 12,3\%-a, addig Pest megyében 32,6\%-a él külterületen. (A községek értékai Hajdú-Biharban $5,0 \%$, Pest megyében pedig $11,0 \%$.)

A megyei általános helyzetet jól visszatükrözi a településenkénti megoszlás (5. ábra) képe is. A szövetkezeti parasztság jelentős területeket foglal el egész Csong. rád megyében, továbbá Bács-Kiskun megye középső, nyugati és északnyugati részein. Szolnok megyében három nagyobb körzet jelölhető ki, míg Hajdú-Biharban, SzabolcsSzatmárban és Békésben inkább csak foltokban jelenik meg.

A gazdasági és társadalmi átalakulás mélyen érintette az egész parasztságot: maga is átalakult és soraiból számosan kerültek át a munkásosztályba, sokan értelmiségi pályára is. Belső rétegződése is lényegesen módosult, ma részben a munkameg. osztás új struktúráját, részben a hagyományokat tükrözi. Tagjai természetesen a réginek számos magatartásbeli és tudati vonását még ma is magukban hordozzák, de az idősebb generáció mellett felnött egy fiatal korosztály, akiknek az életmódjában napjaink hatásai a meghatározóak, így a magasabb mezőgazdasági technika, valamint a magasabb iskolázottság. Átalakult eközben a térbeli eloszlási rendjük is. Számos településben a korábbi meghatározó jelentóségük megcsappant, vagy megszünt. A települések belső struktúrájáról tudjuk, hogy lakóhelyük egyre inkább a zárt települések peremterületére, vagy onnan még távolabbra, a határba szorul ki (BECSEI J. 1983). Sőt: az Alföldön korábban valójában a mezőgazdák által lakott külterületek adták a jellemző sajátosságot, de ezek mára lényegében megszúntek az agrárnépesség otthonai lenni.

\section{3. Értelmiségiek és az egyéb szellemi keresók}

A külterületen élő szellemi aktiv keresők létszámukban és arányukban is a legkisebb társadalmi réteget alkotják. 1980-ban az Alföld külterületén 10002 szellemi fogialkozású élt. Az aktív keresőknek ez 6,7 \%-át jelentette. Jelentőségük azon- 
ban napjainkban létszámuknál lényegesen nagyobb, ami következik a mai kor gazdasági követelményeiből. Az emberi tényező szerepe egyre inkább felértékelödik, egyre fontosabb szerepet fog játszani a magasabb szakmai képzettség az élet minden területén, még akkor is, ha a gazdaság ezt még egyértelmüen nem értékeli magasra, illetve nem kényszeríti ki a minél magasabb általános és szakmai múveltséget. Ma a magasabb iskolai végzettség megszerzésére való törekvés sokszor elsősorban presztízs és csak másodsorban gazdasági kényszer kérdése. A kettő egymástól természetesen nem választható el, de azt tapasztalati tényként is elfogadhatjuk, hogy a gazdasági kényszer csak a szakmai képzettség bizonyos, legfeljebb középszintű elérésére ösztönöz. Ezen belül is egy lefelé nivellálódás érvényesül, különösen olyan, a gazdasági fejlettségben bizonyos mértékig elmaradott területeken, amilyen éppen az Alföld is, különösen annak külterületi településú területei.

Az Alföld összes szellemi keresőinek (380 488) 1980-ban csak 2,7 \%-a élt külterületen, ami természetesen következik abból, hogy a szellemi foglalkozásúak munkahelyei elsősorban a belterületre települnek. Az egyes településeket külön is vizsgálva azonban számos olyan határrészt találunk, ahol a szellemi aktív keresök aránya magas értékeket mutat. lgy pl. Kecskemét határában az aktív keresők közül a szellemiek aránya átlagosan $11,1 \%$, de Városföldön eléri a 24,2 \%-ot, Körösihegyen a 16,4 \%-ot. Bár általában e társadalmi csoport esetében is különbséget találunk a városi és községi külterületek értékei között, de ez a különbség (1,9\%) nem olyan tetemes, mint a munkásság vagy a szövetkezeti parasztság esetében volt. (Annál nagyobb különbség tapasztalható a városi és községi belterületi értékek között, ami mutatja a városok ilyen irányú központositó hatását, s a falvakkal szembeni magasabb fejlettségét.)

A szellemi keresók külterületi alacsony részesedési arányát figyelembe véve jelentős eltérésnek számít az, hogy Szabolcs-Szatmár megyében az arányuk 8,7\%, míg Csongrádban csupán 5,4\%. Ugyancsak Szabolcs-Szatmárban találjuk a legmagasabb $(11,6 \%)$ városi értéket és Csongrádban a legalacsonyabbat $(6,1 \%)$. Csongrádban van a legalacsonyabb $(5,2 \%)$ községi érték is, míg a legmagasabbat $(8,0 \%)$ Hajdú-Biharban figyelhetjük meg. A csongrádi alacsony községi értékhez hasonlót találunk Bács-Kiskun megyében is. A legalacsonyabb szellemi keresői arányokat tehát azon településekben találjuk, ahol a szövetkezeti parasztság a legnagyobb arányban fordul elö, ahol a kertgazdálkodás, a zöldség- és gyümölcstermelés a legintenzívebb.

A szellemi keresők külterületi aránya és a külterületi népesség iskolázottsági szintje között ugyan nem, vagy csak nehezen lehet összefüggést találni, de az tény, hogy a külterületi népesség általános iskolázottsági szintje $(46,6 \%)$ lényegesen alac\$onyabb, mint a belterületi népességé $(59,8 \%)$.

A 15 évesnél idősebb népesség iskolai végzettsége az Alföld egészén is roszszabb, mint az országos átlag, de ezen belül is tekintélyes szóródás jelentkezik. A két szélső értéket Szolnok megye községi külterületi népességének minimuma $(40,3 \%)$ és Szabolcs-Szatmár megye városi belterületi népességének maximuma $(75,6 \%)$ képviseli. Az átlagos alföldi iskolázottságot tekintve is igen jelentős a községi külterületi $(44,4 \%)$ és a városi belterületi $(72,5 \%)$ népesség között a különbség. Mindezt az eltérő korstruktúra nem magyarázza meg (5. táblázat). Az okokat több tényezőben kell keresnünk, amelyek közül a falvak külterületi népességének korösszeté- 
Tér és Társadalom 2. évf. 1988/1. 19-42. p.

紫

宫

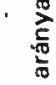

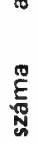

舟学

กำ

ตำก

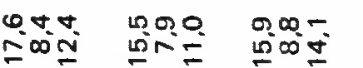

mo

$\infty \pi 8$
000

恶昂

눈

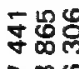

我

Nino

ONo

क्ष०ण

ron

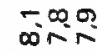

$=00$

承导

ำํํํํํำ

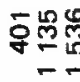

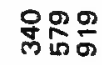

芦紫

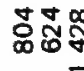

品吉总

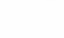

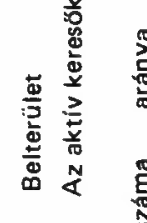

동

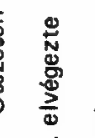

(

요요

Ni:-

ind

$\sqrt{2}$

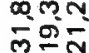

$8 \pi$

लㄷำ

\section{$0 \%$}

लํㅛ

NOำ

ชำ

능ํํㅇ

ำํำ

홍유유

L

mio

ถั้ำช

군

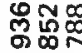

กับู

nิ:

sid

원유

ณกุำ

वृฺ्.

$8 \div$

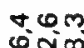

षิ่

$-00$

on

웡ำ

$5 \%$

子कำ

표요

ํㅗำำ

ธั유요

\&ั\%

ิㅗำ

$\frac{\pi}{6} \overline{6}$

ำำ

on $\infty$

กิ่ง

舟学

กับำ

象-

品品

는

ธัष्ठ

祸尔

-

$89 \pi$

Jo

玄哭

ํํํำ

용

ก⿻

กูกิ่ำ

श뭉

ถูก๊

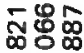

-

$$
\text { 芩 }
$$

$\sum^{2}$

00

รีF

rog

0,0

พ⿻丷木

$0, \infty$

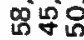

om

ㅎํㅇํำ

นก 0 以ो

웅용

กับ

ํํำ

UN

용

8 in

대요

\&ํํ요

ํํำ

鬲

웅용

$\forall \forall \infty$

๙20

연온

nin

กับ

क्ष

$00 \%$

กา

Ni

-m!

$0 .-$

$10+\infty$

I)

\%

เก 40

Я요 둥

유

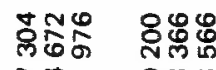

융요

윰

용

도윰

뜸ํㅇㅇ

옷융

등ํำ

Nก่ถ

$=-\frac{1}{2}$

๘

융응ㅇ

앗옹
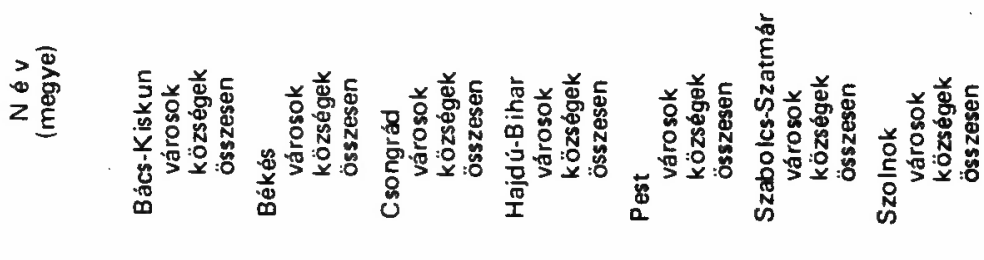
tele csak az egyik tényezỏ lehet, de szerepet játszik a korábbi életmód, az iskoláktól való nagyobb távolság, a foglalkozási szerkezet, amelyek kevesebb lehetóséget teremtenek (másrészt kisebb aspirációt fejlesztenek ki) abba az irányba, hogy minél magasabb iskolai végzettséget szerezzenek a külterületen élök. lgy talán ez - a statisztikai adatokon keresztül is megragadható - helyzet tükrözi vissza leginkább a külés belterületen élök életminósége közötti jelentős eltéréseket.

\section{Kisárutermelök és kiskereskedők}

A kisárutermelök és kiskereskedők rétege az Alföldön a legkisebb létszámú csoport, összesen 64711 föt foglal magában, s ez az összes keresők 3,8 \%-át adja. Ellentétben a már tárgyalt három csoporttal, a külterületen vannak viszonylag többen. Amíg ugyanis az alföldi belterületi keresókből 3,5\%-kal, addig a külterületi keresőkből 7,5 \%-kal részesednek. Létszámuk a külterületen meghaladja (1151 fövel) a szellemi foglalkozásúakét, ellenben a belterületen azoknak csupán 14,5 \%-ával egyezik meg. Más vonatkozásban is másként viselkednek, hiszen a községi belterületi keresókböl 4,1\%-kal, míg a városiakból 2,7\%-kal részesednek. Igy tehát a fõ települési területük a külterület, illetve a községek belterületei, vagyis a fejletlenebbnek minősíthetö településtípusokban viszonylag nagyobb számban élnek.

A külterületen élök csaknem egyenlö arányban találhatók a városok $(7,6 \%)$ és a községek $(7,4 \%)$ külterületén, bár abszolút számukat tekintve a községiek létszáma (7629) több, mint a duplája a városiakénak (3524). Az egyes településtípusok és területek szerint a szóródás (Pest megye városai 4,6\%, Szolnok megye községei $12,6 \%)$ tekintélyes. A legjellemzőbb sajátosságnak mégis az tekinthetö, hogy a BácsKiskun és Csongrád megye területén élók az összesnek a 46,0\%-át adják, míg e két megyének az összes keresöbỏl való részesedése csak $28,7 \%$. Ez a területi koncentrálódás következménye a két megye terütetén, különösen pedig a falvakban folytatott gazdálkodásnak, az ott meghonosodott üzemgazdasági formáknak. Elsősorban a falvakra jellemző: az egészböl e két megye falvaiban él 32,6 \%. Ez az Alföldön belüli területi koncentráció azonban a megyei értékek egybevetése esetén nem mutatkozik meg, hiszen Bács-Kiskun megyében a külterületen élö keresőknek csupán 6,2 \%-át adják, s ennél alacsonyabb hányadot $(4,8 \%)$ csak Pest megye mondhat magáénak.

A külterületi keresőkböl való részesedési arányuk tekintetében Szolnok megye áll az első helyen, ahol a részesedésük $11,1 \%$, a többi megyében mindenütt $10 \%$ alatt marad. Vannak olyan községei az Alföldnek, ahol nemcsak domináns, hanem uralkodó hányadhoz jutnak. Azonban azt is meg kell jegyeznünk, hogy ez a helyzet általában igen alacsony létszámú külterületi kereső esetén áll elő, ahol egy szolgálati lakás (pl. gátöri) jelentősen befolyásolja az átlag mögötti valóságot. 


\section{IRODALOM}

BÁLINT J. 1978: Társadalmi rétegződés és jövedelmek. Budapest, Kossuth Könyvkiadó.

BARANYI B. 1985: A Tiszántúl átalakuló társadalma (1945-1978). Budapest. Akadémiai Kiadó. BECSEI J. 1979: A társadalmi csoportok térbeli elhelyezkedése Békés megyében - Tanulmányok, MSZMP Békés Megyei Oktatási Igazgatósága, Békéscsaba, pp. 59-69.

BECSEI J. 1983: A társadalmi osztályok és rétegek térbeli elhelyezkedése az Alföldön. Alföldi Tanulmányok VII. kötet. Békéscsaba, pp. 103-135.

BECSEI J. 1983: Békéscsaba, Békés, Gyula és tanyavilágának településmorfológiája, Budapest Akadémiai Kiadó.

BELUSZKY P. 1979: Településformáló folyamatok a falusi térségekben. In: Társadalmi struktúránk fejlödése. III. köt. MSzMP KB Társadalomtudományi Intézet. pp. 253-281.

BIHARI M. 1980: A társadalom érdekviszonyai és a szocialista de mokrácia - Társadalmi Szemle, 2. sz. pp. 46-56.

B(RÓ E. (szerk.) 1979: Gazdaság, település, társadalomszerkezet. In: Társadalmi struktúránk fejlődése. IIl. köt. MSzMP KB Társadalomtudományi Intézet

BLASKOVITS J. 1970: A munkásosztály fogalmáról - Társadalmi Szemle, 8-9. szám. pp. 122131.

BÖHM A. 1985: Falun éló munkások. Társadalomtudományi Közlemények 2. sz. pp. 200-211.

CSIZMADIA E. - NAGY S. - ZSARNÓCZAI S. 1966: Az egységes szocialista szövetkezeti parasztosztály kialakulása. Budapest, Kossuth Könyvkiadó.

ENYEDI GY. 1983: A magyar falvak helyzete és jövöfejlödése. Társadalomtudományi Közlemények 1. sz. pp. 42-49.

FARKAS I. 1971: Társadalmunk rétegzödése és a munkásosztály - Társadalmi Szemle 2. sz. pp. $75-83$.

FERGE ZS. 1969: Társadalmunk rétegzödése. Budapest, Közgazdasági és Jogi Könyvkiad ó.

GYENIS J. (szerk.) 1978: Tanulmányok a termelőszövetkezeti parasztságról. Budapest, Kossuth Könyvkiado.

HALAY T. (szerk.) 1973: Tanulmányok a munkásosztályról. Budapest, MSZMP Központi Bizottságának Társadalomtudományi Intézete, Kossuth Könyvkiadó.

HALAY T. 1982: Bevezetés. A társadalmi struktúra kutatásának alapproblémái. Társadalomszerkezet és rétegzödés. Kossuth Könyvkiadó.

P. KÁLMÁN K. (szerk.) 1979: Rétegzódés, mobilitás, egyenlótlenség. In: Társadalmi struktúránk fejlódése. 11. köt. MSzMP KB Társadalomintudományi Intézet

KLINGER A. 1982: Az osztály-és rétegszerkezet változásai. Társadalomszerkezet és rétegzödés. Kossuth Könyvkiadó.

KOLOSI T. 1981: Az értelmiségról vitatkozva - Társadalmi Szemle, 8-9. sz. pp. 119-128.

KOVÁCS Cs. - FRANCIA L. 1979: A települések társadalmi szerkezete és az anyagi életkörülmények. In: Társadalmi struktúránk fejlödése. III. köt. MSzMP KB Társadalomtudományi Intézet. pp. 179-251.

MILTÉNYI K. 1981: Az értelmiség mobilitása, rétegzôdése és helyzete 1945 után - Társadalmi Szemle, 8-9. sz. pp. 129-133.

MÓD A.-NÉ 1970: Korunk és a munkásosztály - Társadalmi Szemle, 6. sz, pp. 83-97.

ORBÁN S. 1983: Átalakuló parasztság - változó parasztpolitika. Társadalomtudományi Közlemények 1. sz. pp. 36-42.

SıMó T. 1980: A termelószövetkezeti dolgozók társadalmi tagozódásáról - Társadalmi Szemle. 8-9. sz. pp. 60-66.

SIMÓ T. 1984: Állami gazdaságok és termelöszövetkezetek fizikai dolgozóinak jellemzóiról. Társadalomtudományi Közlemények 4. sz. pp. 549-557.

SiMó T. 1986: A szakszövetkezetek és a települések gazdasági-társadalmi struktúrája. Társadalom. tudományi Közlemények 1. sz. pp. 90-101.

?.IRMAI V. 1985: Térbeli társadalmi problémáink és a településtervezés felelóssége. Társadalomtudományi Közlemények 3. sz. pp. 438-447. 
VÁRNAI Gy. (szerk.) 1979: Társadalmunk szerkezetének fejlódéstendenciái. In: Társadalmi struktúránk fejlödése. I. köt. MSzMP KB Társadalorntudományi Intézet

VÁRNAI GY. 1985: Társadalmi rétegződés Magyarországon 1962-1981. (Adatok az egyenlötlenségi rendszer változásairól.) Társadalomtudományi Közlemények 1. sz. pp. 24-36.

JÓZSEF BECSEI

\title{
STRATIFICATION AND SPATIAL DISTRIBUTION OF POPULATION LIVING IN THE OUTSKIRTS OF ALFÖLD SETT LEMENTS 1980
}

\author{
(Surnmary)
}

There are extensive surveys, analyses and debates in social sciences concerning the changes in Hungarian society, its restructuration, but a scientific representation of the spatial aspects of these processes in still missing.

The present paper aims at analysing the population living in the outskirts of Alfold settlements from this aspect.

(The distinction between inner areas and outskirts or outer areas of settlements is made for planning purposes. The inner area is the built-up, developed area or the territory to be developed; the outer area serves primarily agricultural, recreational etc. purposes. Nevertheless, Hungarian towns and villages, particularly in the Alföld, have people living in the outskirts, often in detached tarmsteads.

The translator.)

Data from the 1980 census were used for these purposes accepting the statistical concept of social structuration. Detached farmsteads represent a specific formation within the Hungarian settlement system. Their developments differ from the overall societal processes in many ways and this divergence has not been adequately dealt with in scientific research. During the past four decades population living in detached farmsteads has significantly decreased. In 1980 only $8.8 \%$ of the Alföld population lived in the outskirts. There are extensive areas in the Alföld where there are no more inhabited farmsteads but in other areas (in Bács-Kiskun and Csongrád counties) the number of people living in detached farmsteads is still significant.

The social structure of population in the outskirts has markedly changed. The working class has an important $(49.3 \%)$ representation within the active residents, with an over $50 \%$ or dominant percentage in several settlements. In the Alföld the relative weight of the other major social class, the collective farm peasantry is smaller than this: $38.1 \%$. The working class is in majority in the outskirts of towns while co-operative peasants live in the outer areas of villages. The age structure and the education level of industrial workers are better than the similar composition indices of those who work in agriculture. Collective farm peasantry is over-represented in the outskirts of disadvantaged settlements. Another characteristic feature of outer areas is that they have a larger percentage of small-scale producers within their active residents than inner areas.

The analyses made leave us without any doubt over the neccessity of further research, by \$patial scientists, into the social changes in the outskirts of settlements.

Translated by Eta Daróczi 
БЕЧЕИ. ЙОЖЕФ

\section{РАСЧЛЕНЕННОСТЬ И ПРОСТРАНСТВЕННОЕ РАЗМЕЩЕНИЕ ОБЩЕСТВА АЛЬФЁЬДА, ЖИВУЩЕГО ВНЕ НАСЕЛЕННЫХ ПУНТОВ, В 1980-М ГОДУ}

(Резюме)

Изменения, преобразование структуры, а также настоящая классовая структура и слоистость венгерского общества широко обследуются, анализируются и обсуждаются в кругах общественных наук, все же, наука в общем остается в долгу дать отсчет о пространственном появлении всего этого.

В настоящей статье ставится задача проаналиэировать общество Альфёльда, живущее вне населенных пунктов, с таких аспектов. Для исследования были использованы данные переписи населения 1980-го года, и при этом были приняты официальные статистические категории в отношении структуры общества.

Рассуждаемая проблематика тем более интересна, что здесь речь идет о специальной части системы расселения в Венгрии, которой в последние годы наука мало уделяга внимание, И которая, в отношении общества, имеет немало отличительных черт. За поспедние четыре десятка пет число населения вне черты поселений значительно уменьшилось; в 1980-м году үже лишь 8,8 процента общего населения Альфёльда жило в таких частях. На Альфёпьде имеются такие обширные территории, где по существу уже не остапось населения на околицах, а в других районах (медье Бач-Кишкун и Чонграр), наоборот, и в настоящее время многие живут на хуторах (танья). При всем этом в зани'тельной мере преобраэовалась внүтренняя структура общества вне населенных пунктов. Значительная доля эанятого населения $(49,3 \%)$, живущего за пределами поселений, относится уже к рабочему классу; в случае многих поселений их удельный вес превышает и 50 процентов, а нередко рабочие даже дают доминирующее количество. В то же время, доля другого большого класса, кооперативного крестьянства, эдесь больше $(38,1 \%)$ чем по Альфёльду в иелом.

В случае городов, вне населенного пункта в первую очередь живут рабочие, а для сельских посепений характерно кооперативное крестьянство. Из опытов можно сделать обобщение, что внутренняя структура рабочего класса (по возрасту, по образованию) более желательная, чем то же в случае кооперативного крестьянства, далее, что кресть янство в большем количестве живет на околицах менее развитых поселений. Можно считать характерным и то, что удельный вес мелких товаропроизводителей в общем числе занятых больше в насепении вне черты поселений, чем среди активного населения в собсгвенных населенных пунктах.

Проведенные исследования убедили нас в том, что требуются дальнейшие работы по анаэиэу изменений общества вне черты населенных пунктов, что, в свою очередь, должно ставить новые задачи перед пространственными науками."

Перевел: Тамаш Бауко 